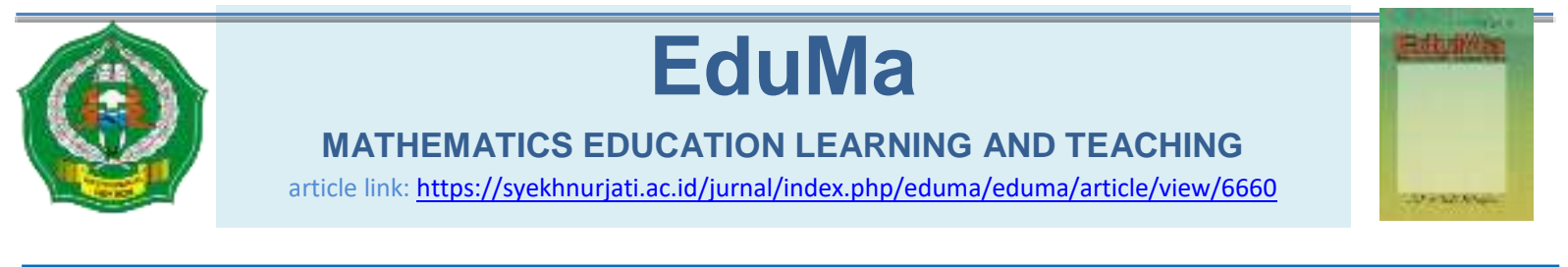

\title{
Development of Android Application Learning Media "Ruang Trigonometri" for Semester I Students of Mathematics
}

\section{Putu Suarniti Noviantari}

Department of Mathematics Education Faculty of Teacher Training and Education, UNMAS Denpasar

Corresponding author: Denpasar, Bali, 80237, Indonesia. e-mail addresses: pts.noviantari@unmas.ac.id

\section{A rticleinfo \\ How to cite this article: \\ Noviantari, P.S. (2020). Development of \\ Android Application Learning Media "Ruang \\ Trigonometri" for Semester I Students of \\ Mathematics. Eduma : Mathematics Education \\ Learning and Teaching, 9(2), 1 - 10. \\ doi:http://dx.doi.org/10.24235/eduma.v9i2.6660}

Article history:

Received: 06 18, 2020

Accepted: 11 11, 2020

Published: 12, 2020

Copyright (C) 2020

EduMa: Mathematics Education

Learning and Teaching under the

Creative Commons Attribution 4.0

International License.

\begin{abstract}
DEVELOPMENT OF ANDROID APPLICATION LEARNING MEDIA "RUANG TRIGONOMETRI" FOR SEMESTER I STUDENTS OF MATHEMATICS. This study aims to (1) produce learning media based on android learning (2) to know the level of feasibility of learning media according to material experts, media experts, and users, (3) to know the effectiveness of learning media to improve the learning outcomes of Senior high school students. This development study follows the steps developed by Alessi and Trollip, consisting of three stages: planning, designing, and development. Initial product validated by media expert and material expert then revised. The next stage is a small group beta test carried out to ten prospective users and tested on 5 users. Furthermore, test against 20 students. The results showed that (1) android-based mobile learning products packaged in android package format (apk) using app geyser software. (2) mobile learning product is considered feasible as a learning media based on the assessment of media experts 3,9 and material experts 4.2 with the category of very good. (3) the effectiveness of the product is evidenced by the increase of learning outcomes to reach the average score of pretest score 65 and post-test of 80
\end{abstract}

Ke y word s :

Instructional media; android application; trigonometry 


\section{INTRODUCTION}

The development of science and technology nowadays causes almost all human activities controlled by Science and Technology. The result of science and technology requires an effort to make it easier to find out about these sciences (Wiyono, 2012). The development of science and technology is in line with the current teaching and learning process. In teaching and learning activities, the teacher only functions as a facilitator who provides students' facilities to learn; the teacher acts as a motivator, mentor, guide, and driving force in the learning process to take place effectively.

Based on the interviews with five students participating in studying the Trigonometry course at the Department of Mathematics Education of FKIP Unmas Denpasar (28 May 2019), several problems were found in the 2018/2019 academic year, namely in the trigonometric identity material. Students need a lot of practice and deep understanding. In this case, learning the media's role is very important so that the quality of learning and student understanding increases.

Learning media can be developed on mobile devices that are easy to carry anywhere, such as smartphones (Squire, 2009). Students can also easily interpret data, increase understanding, compress information, present data, generate motivation and interest in students in learning so that students do not only listen to explanations from the teacher, but through learning media, students can also make more observations and demonstrations (Sudjana \& Rivai, 2011). The development of media in the form of the Ruang Trigonometri Application is thought to meet the criteria for supporting the objectives and content of learning, conformity to student characteristics, the efficiency of learning time, and easy use by students.

Applications are part of electronic learning or better known as e-learning (Georgiev \& Smrikarov, 2006). In principle, the application aims to make it easier for learners to learn anywhere and anytime, according to their time. The Ruang Trigonometri application can be accessed virtually from anywhere by providing access to all different learning materials. The Ruang Trigonometri application also provides online questions so that students can take tests and see the results.

The presence of the application can support the concept of lifelong education. The nature of the application based on open source makes it possible for everyone to develop and use it according to the wants and needs of learning (Belina \& Batubara, 2013). E-learning generally has a search feature according to user preferences so that various types can be quickly searched and found. Based on the opinion, one of the essential factors influencing the transfer of concepts from printed learning resources to electronic formats is the ease of accessibility (Jones and Brown, 2011).

Android is a Linux-based mobile operating system developed by Androin Inc. and later acquired by Google. Android is a software used on mobile devices, including operating systems, middleware, and core applications (Purwantoro et al., 2013). Android is an operating system for smartphones and tablets (Satyaputra and Aritonang, 2014). Argues that android is a Linux-based operating system specifically for mobile devices such as smartphones or tablets (Huda, 2013).

Android's advantages are taking a comprehensive approach, being an opensource, free platform, and operating system that is widely used. At the same time, android's weakness is always connected to the internet and does not save battery power (Zuliana and Irwan Padli, 2013). Then the development of learning must be designed and supported by learning media so that it can increase students' understanding of Trigonometry material. The product of Android-based learning media becomes a new alternative in exciting and fun learning. Research regarding the Development of Learning Media Based on Android in the Education Statistics course that produced learning media based on android in the right 
Education Statistics course, Student response to learning media is very good (Purnomo E.A et al., 2018).

Learning is a process of assimilation and accommodation, which is carried out systematically. In addition to behavior and cognitive theories, the constructivist approach is also very influential in developing mobile learning media because an increase in student understanding occurs due to learning (Darmawan, 2014). Constructivist theory on the development of learning media for android applications can underlie significant aspects of curiosity and increased student creativity through a material presentation about the excretion system and supported by question exercises.

The development of learning media can meet students' needs if it is studied in the field of learning technology. Learning technology has a role in facilitating learning and improving performance by creating, using, or utilizing and managing appropriate technological processes and resources (AECT, 2004). Educational technology is human learning, so recently, the term educational technology tends to be replaced by learning technology (Miarso, 2004).

The development of learning media cannot be separated from the role of learning technology, namely theory and practice, in the design, development, utilization, management, and evaluation of learning processes and resources. In learning technology, the relationship between regions is synergetic. The result of teaching media for android applications focuses not only on the development area or coverage of the region but also on theory and practice from the other regions. This research aims to produce a feasible and practical Ruang Trigonometri application learning media for students.

\section{METHODS}

This research is a type of research $R$ \& D (Research and Development). This study aims to produce a feasible and practical Android-based learning application for students. The development model used in this research is the Alessi and Trollip development model.

At the planning stage, the steps taken include (1) defining the scope of the material carried out through observation and interviews, (2) identifying student characteristics, namely by using the needs analysis sheet, (3) determining and collecting sources, namely sources which relates to other materials and references, and (4) conducts brainstorming with Trigonometry lecturers to create a design concept for learning media development.

At the design stage, the steps are (1) developing media that includes layout, navigation buttons, color types, and text size in the android application. (2) analyzing concepts and assignments related to the learning content, (3) making flowcharts to display the program structure from beginning to end, and (4) determining the software used.

At the development stage, the steps taken include (1) preparing the text material, which is processed using Microsoft Office Word software (2) preparing text, video, and image content, (3) preparing the google sites website, which is then exported using the app geyser application, so that produce a file with an app extension, (4) prepare supporting material including additional online questions via a google form, (5) conduct an alpha test on two media experts and two Trigonometric material experts, and conduct beta tests on 20 students.

Conduct this trial to test the feasibility of the product being developed. The trials in this study include alpha testing and beta testing. The alpha test was conducted by two media experts and two material experts. Assessment by media experts includes aspects of audiovisual display and software engineering. Assessment by material experts includes aspects of learning and material content.

Validation by media experts and material experts is carried out by exploring the Android application packaged in the application package (app) format and then 
assessing the Android application based on the assessment aspects listed in the media expert and material expert validation questionnaire.

A beta test is conducted on students to find out the user's response to the android application. The aspects tested in the beta test include ease of use and clarity of the material. The beta test is carried out in two stages: the small group test, which is tried out on three students with high, medium, and low ability levels. Small group trials are intended to determine the initial response and program performance when operated by the user, while the large group test is tested on 20 students.

The test subjects in this study were 20 students for beta testing and obtaining an assessment of the response of the android application user from the user's side.

The techniques used to collect data in this study include interviews, questionnaires, and tests. The instruments used in this study were The techniques used to collect data in this study include interviews, questionnaires, and tests. The tools used in this study were interview guides, media expert validation questionnaires, material expert validation questionnaires, and user response questionnaires. The form of interview used in this study was free, guided interviews. Interviews were conducted using interview guidelines that contain the main issues to be studied. The results of the interview were used to obtain data about learning difficulties in trigonometric material.

The questionnaire was used to determine the appropriateness of the application from media experts and material experts, as well as to determine the user's response to the Ruang Trigonometri Application learning media. The media expert validation questionnaire was given to two media experts to assess the feasibility of teaching media for the Trigonometry Room Application based on audiovisual display and software engineering aspects. The material expert validation questionnaire was given to two material experts to determine the Ruang
Trigonometri Application learning media's feasibility based on the learning aspects and the content of the material.

Questionnaires for user responses include aspects of ease of use and clarity of the material. This questionnaire is used to obtain a proper assessment of the Trigonometric Application learning media based on user responses. The results of the evaluation and suggestions from both media experts and the two material experts, as well as the results of observations and assessment of user responses, are used as the basis for revising learning media products for the Ruang Trigonometri Application.

The data obtained from this research instrument were qualitative and quantitative data. The data analysis technique used in this study used qualitative data analysis techniques, qualitative descriptive data analysis for the product's results. In contrast, quantitative analysis was analyzed by changing the average score into a quantitative value with assessment criteria to assess an android application product's feasibility. Conversions made to quantitative data refer to the conversion formula on a scale of five (Sukarjo 2006: 53) presented in Table 1.

Table 1.

Conversion of Quantitative Data with a Scale of Five

\begin{tabular}{lll}
\hline Scale & Score Interval & Category \\
\hline 5 & $\mathrm{X}>4,21$ & Very good \\
4 & $3,40<\mathrm{X} \leq 4,21$ & Good \\
3 & $2,60<\mathrm{X} \leq 3,40$ & Enough \\
2 & $1,79<\mathrm{X} \leq 2,60$ & Less \\
1 & $\mathrm{X} \leq 1,79$ & Very less \\
\hline
\end{tabular}

The conversion of scores into criteria is used as recommendations in determining the feasibility and quality of a product being developed. Quality must also be supported by the effectiveness of a product being developed; according to Hake (2007: 8), a product can be effective through learning outcomes. Student learning 
outcomes are a measuring tool to determine students' cognitive abilities. The increase in learning outcomes can be determined by calculating the gain value (normalized gain or $\mathrm{N}$-gain).

\section{RESULT AND DISCUSSION}

The results of the development in this study, namely the Android-based Trigonometry application learning media for the trigonometry course for students in the Trigonometry course using the app geyser software which is packaged in the android package (app) format with the following details.

The final product of the learning media Android application for students is in an app file. The file must previously be sent via WhatsApp to the student class group to be downloaded and installed to use it. This product consists of a cover page, a curriculum page, a material page, a bibliography, a page of practice questions, a page, a video page, and a developer profile page. The cover page in the Trigonometry Application learning media contains information about the university logo and application name. The main menu page includes several buttons that can open other application views such as curriculum, material, bibliography, and Developer Profile.

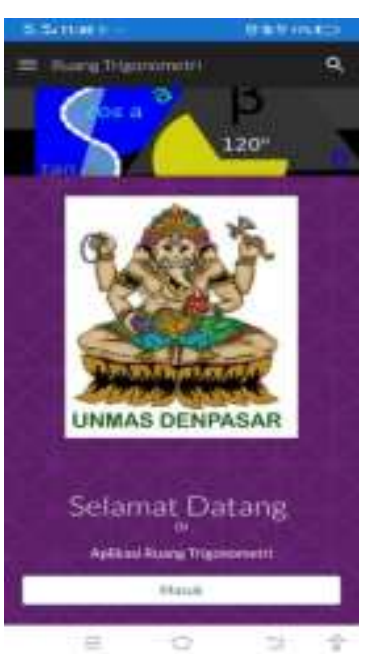

Figure 1. Cover

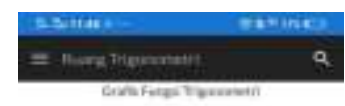

Persamaan

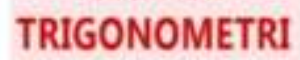

Contoh saat dan Aumus

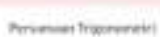

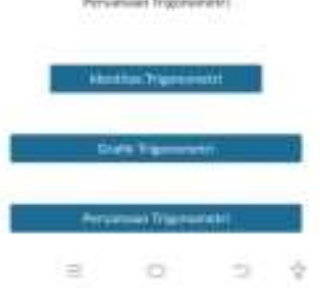

Figure 2. Menu
The menu page contains cover pages, menu pages, material pages, practice questions, learning videos, submitting assignments. The following is a menu page image on the Ruang Trigonometri application.

The material page is a display consisting of three the materials, namely Trigonometric Function Graphs, Trigonometric Identities, and Trigonometric Equations. In addition to the material display, there is also a menu display for instructional videos. The following is a picture of the material page and the Trigonometry learning video.
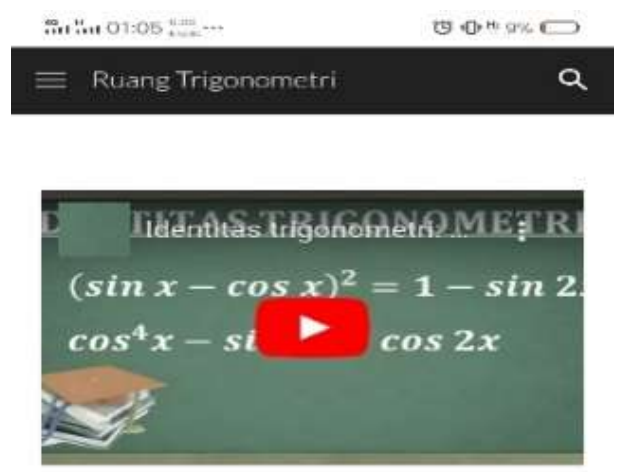

GRAFIK TRIGONOMETRI

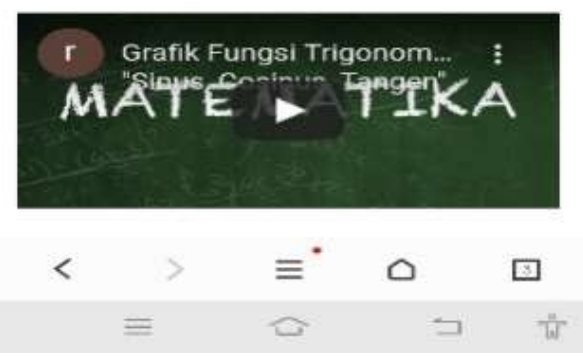

Figure 3. The learning video on the Ruang Trigonometri application

The evaluation page can be accessed by selecting the question menu for each material. The question display is accessed, the application will display the identity filling and multiple-choice questions, with a point for each item. The following is a picture of the evaluation page in the Ruang Trigonometri application learning media. 


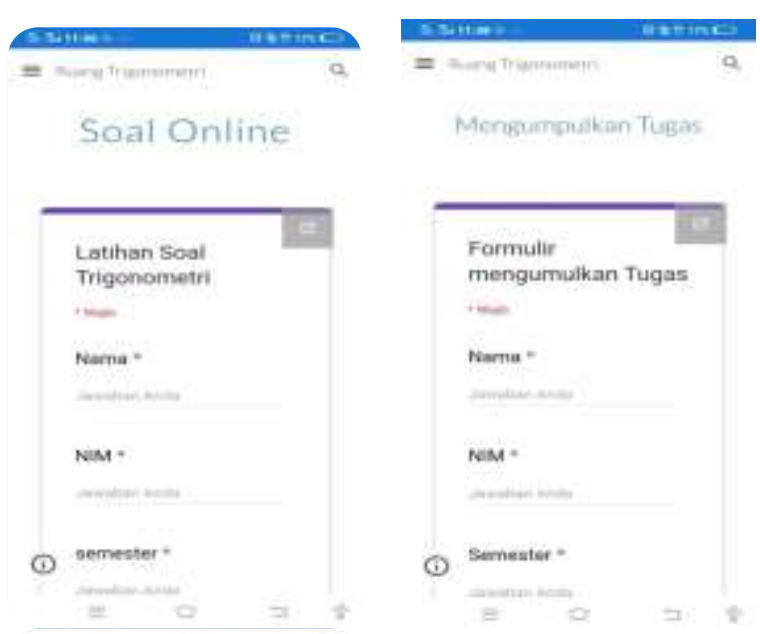

Figure 4. Exercise and Assignment Question Page

Android application learning media products have been developed by the development stages of Alessi \& Trollip's multimedia learning, including planning, design, and development, which is equipped with attributes in each development stage, namely standards, continuous evaluation, and project management. The process of developing learning media for the android based Ruang Trigonometri Application is by the theory of multimedia development, according to Alessi \& Trollip (2001: 411). The results in planning the development of the Ruang Trigonometri application starts from planning, namely defining the area/scope of use of trigonometric space products intended for 1st-semester students, identifying student characteristics by providing a questionnaire of needs to students who want applications that can help to understand trigonometry subjects, determine and collect resources for the subject of trigonometry with the subject matter Comparison of right triangles, calculations on right triangles, the concept of trigonometric comparisons for related angles, graphs of trigonometric functions and the concept of trigonometric identities.

The design process is developing the main idea's content by selecting and selecting the material to be used, analyzing concepts and tasks by determining the indicators to be achieved, and detailing available material into more specific material components, making flowcharts storyboards to describe the workflow and intricate details. It can be seen in the application view. The development process begins with preparing all the teaching materials related to the trigonometric material, combining each part obtained, then drilling the supporting materials, and making an application program using the app geyser software, carried out by alpha testing media material experts.

After the product has been developed, it is validated by material experts and media experts. The material expert validation process aims to measure and assess aspects of learning and the material packaged material in the Android application product. It aims to produce excellent and feasible products in terms of learning and material content.

In addition to material validation, validation from media experts aims to measure the feasibility of the media being developed before it is used at the next development stage. The two media experts were given an instrument to assess the overall quality of the product. Media expert validation consists of aspects of audiovisual display and aspects of software engineering.

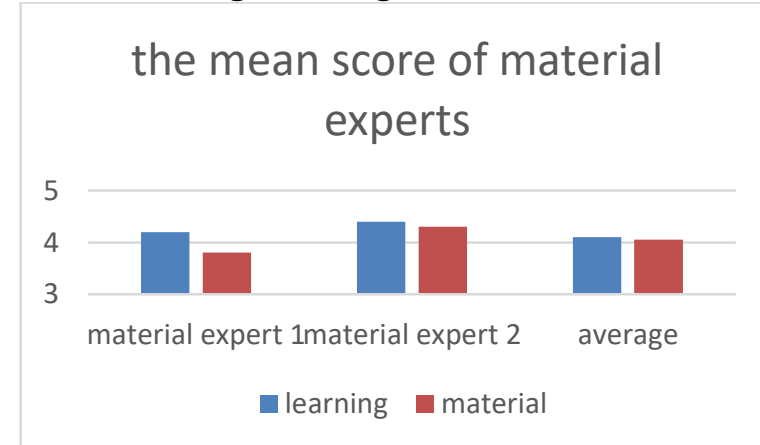

Figure 5. Material Expert Validation Diagram

The material expert's diagram image shows that the material expert's validation results are in a good category; this is based on the average score of the two material validators showing the number 4.2 . The score is based on the average result of the material expert validation score, one from each aspect, namely the learning aspect with an average of 4.2 and the material 
content with an average of 3.8 and is in the very good category. Furthermore, the expert validation of material two from each aspect, namely the learning aspect, is 4.4, and the material content aspect is 4.3 and is in the very good category. Furthermore, the results of the media expert validation are as shown in Figure 6.

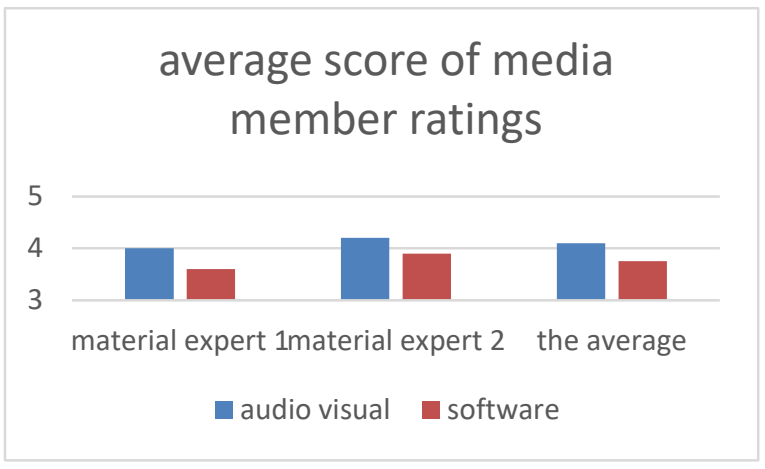

Figure 6. Validation Diagram of Media Experts

The media expert's diagram image shows that the two media experts' overall validation results are 3.9 ; this indicates that the assessment of the two media experts is in a good category. The mean score is described in the achievement of each aspect's mean score, including the audiovisual display aspect reaching a score of 4.1 and software engineering, achieving a score of 3.7 with good criteria. In the small group, a beta test, as shown in Figure 7.

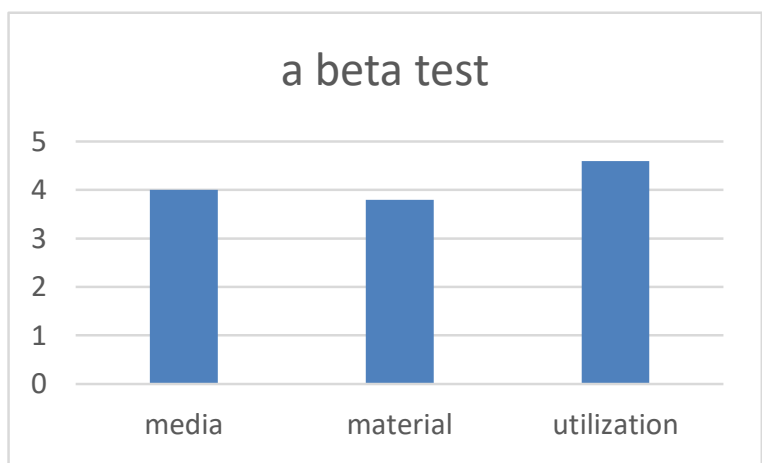

Figure 7. Small-Group Beta Test Diagram

The small group reviewed consists of 3 students who have high, medium, low ability levels. This is viewed from the aspects of media, material, and utilization. The learning media product developed reaches an average score of 4.1 and is included in the very good criteria.

The large group beta test to assess the Trigonometric Room Application products was carried out on 36 students by providing learning programs and Likert scale instruments to assess the quality of learning media consisting of media aspects reaching a score of 4.2 , learning aspects are getting a score of 4.4 , and aspects of utilization. They have achieved a score of 4.3. The average score obtained from the three elements reached 4.3 and was included in the very good category.

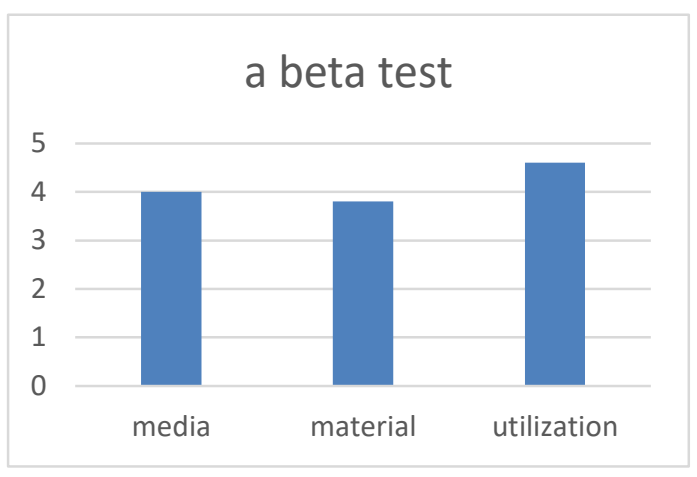

Figure 8. Large Group Beta Test Diagram

The pretest and post-test were carried out on the trigonometry subject as the test subject for Android application users. Data from the pretest and post-test results in the trigonometry course can be seen in table 2 .

Table 2.

Results of Pretest and Posttest of Mathematics Student

\begin{tabular}{cccc}
\hline No & Variable & $\begin{array}{c}\text { Pre } \\
\text { test }\end{array}$ & $\begin{array}{c}\text { Post } \\
\text { test }\end{array}$ \\
\hline 1 & The highest score & 80 & 90 \\
2 & Lowest Value & 50 & 70 \\
3 & Average & 65 & 80 \\
4 & Gain & \multicolumn{2}{c}{15} \\
\hline
\end{tabular}

Based on Table 2, it can be seen the changes that have occurred. The average pretest score was 65 , and the post-test was 
80. The increase in learning outcomes occurred with a gain score of 15 . From the student test results, it can be stated that there is an increase in value so that the Trigonometric application product is feasible to use. The effect of applying the trigonometric space on the results of student test scores is because students can learn through the application of the Ruang Trigonometri, in the form of text, images, videos, illustrations, and questions anytime, anywhere, repeatedly and independently.

The percentage of students passing the pretest test was $19.4 \%$, as many as seven people, and at the time of the post-test implementation, it was $100 \%$, that is, all students achieved this score. Based on the trial phase, the Android-based Trigonometry application learning media effectively improves student learning outcomes. This is in line with Nanang and Rusgianto's (2016) research on Trigonometric Learning Multimedia Development using Adobe Flash CS3 at SMA UII Yogyakarta, stating that development results form of multimedia learning mathematics is declared effective based on the results of student achievement tests. From the learning results, achievement tests consistently state that multimedia learning mathematics can improve students' mathematics learning achievement, $81.11 \%$ of students have reached the KKM.

This Trigonometric application learning media has several advantages, namely (1) the presentation of material in the mobile learning product is very easy to operate, (2) this application product is interactive so that it can actively attract student attention, (3) the Android application product can be opened anywhere and repeated.

The shortcomings of this Android application product are (1) the developed Android application product does not contain animated content considering that the application file size capacity will increase when added to the application, and (2) an internet connection is required to open the application.

\section{CONCLUSIONS AND IPMPLICATION}

This research produces learning media for Android-based Trigonometry Applications for students of Semester I Department of Mathematics Education, FKIP Unmas Denpasar in the form of an Android application product that is packaged in a package application format (app). The Trigonometry application learning media is considered very good to use based on the results of the alpha test with an average score of the material experts of 4.2 and an average score of media experts of 3.9 and based on the results of the small group beta test obtaining an average of 4.1 The results of the large group beta test received an average of 4.3. Simultaneously, the percentage of students passing the pretest was $19.4 \%$ and at the time of implementing the posttest was $100 \%$.

The learning media for Trigonometry applications for junior high school students of Department of Mathematics Education at FKIP Unmas Denpasar are by the learning design, by the syllabus and lesson plans and have gone through validation by media experts, material, and student responses, so the use in terms of learning can be implemented by lecturers who teach Trigonometry subjects. Teachers are expected to operate the Trigonometry Application as a medium in the effective learning process to increase students' understanding of the material being introduced to improve student learning scores.

\section{REFERENCES}

AECT. (2004). Defenisi teknologi pendidikan satuan tugas defenisi dan terminologi AECT : Seri Pustaka teknologi pendidikan. Jakarta : PT. Raja Grafindo Persada.

Alessi, S.M. \& Trollip, S.R., (2001). Multimedia for learning methods and development. Massachusetts: Pearson Education, Inc. 
Belina, E. P \& Batubara, F.R. (2013). Perancangan dan implementasi aplikasi elearning versi mobile berbasis android. 4(3),76-81. Retrieved from https://jurnal.usu.ac.id/index.php/si nguda ensikom/article/view/4138

Darmawan, D. (2014). Pengembangan elearning. Bandung: Rosdakarya.

Georgiev, T et al., (2005). "A general classification of Aplikasi Android systems." International conference on computer systems and technologies. Compsystech. Retrieved from https://www.researchgate.net/profile /Tsvetozar_Georgiev2/publication/30 1673819_A General Classification of_Mobile_Learning_Systems/links/ 5720c34208aed056fa290fa8.pdf

Huda, A. A. (2013). Live coding! 9 aplikasi android buatan sendiri. Yogyakarta: Andi.

Jones, T \& Brown, C., (2011). Reading engagement: a comparison between ebooks and traditional print books in an elementary classroom. International Journal of Instruction, 4(2), 6-22. Retrieved from http://www.eiji.net/dosyalar/iji_2011_2 1.pdf

Khuzaini, N., \& Santosa, R. H. (2016). Pengembangan multimedia pembelajaran trigonometri menggunakan adobe flash CS3 untuk siswa SMA. Jurnal Riset Pendidikan Matematika, 3(1), 88-99. https://doi.org/10.21831/jrpm.v3i1.9 $\underline{681}$

Miarso, Y. (2005). Menyemai benih teknologi pendidikan. Jakarta; Kencana.

Purnomo, E. A., Dalyono, B., \& Handayani, S. (2018). Pengembangan Media Pembelajaran Berbasis Android pada Matakuliah
Statistika Pendidikan. Jurnal Karya Pendidikan Matematika, 5(2), 117120.

https://doi.org/10.26714/jkpm.5.2.20 $\underline{18.117-120}$

Purwantoro, S., Rahmawati, H., \& Tharmizi, A. (2013). Mobile searching objek wisata Pekanbaru menggunakan Location Base Service (LBS) berbasis android. Jurnal. Politeknik Caltex Riau, 1(14), 176184.

Sudjana, N., \& Rivai, A. (2011). Media Pengajaran. Bandung: Sinar Baru Algensindo

Sukarjo. (2006). Kumpulan materi evaluasi pembelajaran (Jurusan Teknologi PembelajaranProgram Pascasarjana Universitas Negeri Yogyakarta)

Surachman, Surjono. (2017). Pengembangan adaptive Aplikasi Android pada mata pelajaran biologi SMA sebagai upaaya mendukung proses blanded learning. Jurnal Inovasi Teknologi Pendidikan, 4 (1), 26-37.

https://doi.org/10.21831/jitp.v4i1.972 $\underline{3}$

Squire, K. (2009). Mobile media learning: multiplicities of place. On the Horizon 17 (1), 70-80. https://doi.org/10.1108/10748120910 $\underline{936162}$

Wilson, M., \& Bolliger, D. U. (2013). Mobile learning: endless possibilities for allied health educators. Journal of Diagnostic Medical Sonography, 29(5), 220-224. https://doi.org/10.1177/87564793135 $\underline{03734}$

Wiyono, K., Setiawan, A., \& Paulus, C. T. (2012). Model Multimedia Interaktif Berbasis Gaya Belajar Untuk Meningkatkan Penguasaan Konsep Pendahuluan Fisika Zat Padat. 
Jurnal Pendidikan Fisika Indonesia,

8(1), $\quad$ 74-82.

https://doi.org/10.25273/jpfk.v1i2.15 